\title{
Chapter 26 \\ Environmental Transfer of Carbon-14 in Japanese Paddy Fields
}

\author{
Nobuyoshi Ishii, Shinichi Ogiyama, Shinji Sakurai, Keiko Tagami, \\ and Shigeo Uchida
}

\begin{abstract}
It has been recognized that carbon-14 $\left({ }^{14} \mathrm{C}\right)$ is one of the dominant radionuclides affecting dose from transuranic (TRU) wastes. This radionuclide has a decay half-life of 5,730 years, and ${ }^{14} \mathrm{C}$ organic materials have very low sorption properties to clay and rock in the environment, which raises some concerns about the releases of ${ }^{14} \mathrm{C}$ to the biosphere from radioactive waste repositories. For the safety assessment of TRU waste disposal, we studied the behavior of ${ }^{14} \mathrm{C}$ in rice paddy field soils. We also determined key parameters such as soil-soil solution distribution coefficients $\left(K_{\mathrm{d}} \mathrm{s}\right)$ and soil-to-rice plant transfer factors (TFs) of ${ }^{14} \mathrm{C}$ in the field soils. The TFs were obtained in laboratory and field experiments. In our laboratory experiments, we used $\left[1,2-{ }^{14} \mathrm{C}\right]$ sodium acetate as a source of ${ }^{14} \mathrm{C}$ because it has been suggested that low molecular weight organic- ${ }^{14} \mathrm{C}$ compounds are released from metallic TRU wastes. The results showed that ${ }^{14} \mathrm{C}$-bearing sodium acetate in irrigated paddy soils was rapidly decomposed by indigenous bacteria. Although some of the ${ }^{14} \mathrm{C}$ was assimilated into the bacterial cells, most of the ${ }^{14} \mathrm{C}$ was released into the air as gaseous compounds. The main chemical species of ${ }^{14} \mathrm{C}$ gases was ${ }^{14} \mathrm{CO}_{2}$, and a part of the released ${ }^{14} \mathrm{CO}_{2}$ gas was used by rice plants during photosynthesis. Only a negligible amount of ${ }^{14} \mathrm{C}$ was absorbed through the roots. Therefore, the contamination of rice plants is mainly caused by gasification of ${ }^{14} \mathrm{C}$, and microorganisms are responsible for driving this process. The activity of microorganisms is a key issue in the behavior of ${ }^{14} \mathrm{C}$ in paddy fields.
\end{abstract}

Keywords Bacteria $\bullet$ Behavior $\bullet$ Degradation $•$ Radiocarbon $\bullet$ Rice paddy fields - Safety assessment $\bullet$ TRU wastes

\subsection{Introduction}

Transuranic (TRU) wastes contain a variety of radionuclides, for example, $\mathrm{Np}, \mathrm{Pu}$, and long-lived radionuclides such as ${ }^{14} \mathrm{C}$ and ${ }^{129} \mathrm{I}$. In Japan these wastes are categorized into four groups in accordance with their physical properties and the

N. Ishii $(\varangle) \cdot S$. Ogiyama $\bullet$ S. Sakurai $\bullet$ K. Tagami $\bullet$ S. Uchida

Research Center for Radiation Protection, National Institute of Radiological Sciences,

4-9-1 Anagawa, Inage-ku, Chiba 263-8555, Japan

e-mail: nobu@nirs.go.jp 
concentration of radioactive materials. Group two waste includes hull and end piece wastes with relatively high amounts of ${ }^{14} \mathrm{C}$, and leaching of low molecular weight ${ }^{14} \mathrm{C}$ organic materials from simulated hull wastes has been reported [1]. The ${ }^{14} \mathrm{C}$ organic materials have very few sorption properties to clay and rock, and ${ }^{14} \mathrm{C}$ has a relatively long half-life of 5,730 years. These properties raise concerns about releases of ${ }^{14} \mathrm{C}$ to the biosphere from radioactive waste repositories.

Rice is a major agricultural crop throughout Asia, and thus human exposure to ${ }^{14} \mathrm{C}$ through rice intake must be considered. To reduce the risk of the internal radiation dose from ${ }^{14} \mathrm{C}$, it is important to clarify the behavior of ${ }^{14} \mathrm{C}$ in rice paddy fields. In this study, we determined transfer pathways of ${ }^{14} \mathrm{C}$ through the rice paddy fields to rice grains. Environmental parameters such as soil-soil solution distribution coefficients $\left(K_{\mathrm{d}} \mathrm{s}\right)$ and soil-to-rice plant transfer factors $(\mathrm{TFs})$ of ${ }^{14} \mathrm{C}$ were also determined, because these parameters are often used in transfer models to predict the behavior of radionuclides in the environment. From a series of our experimental results, we describe the behavior of ${ }^{14} \mathrm{C}$ in rice paddy field soils and the importance of microbial activity.

\subsection{Partitioning of ${ }^{14} \mathrm{C}$ into Solid, Liquid, and Gas Phases}

We carried out batch sorption experiments using 63 Japanese rice paddy soil samples to clarify the transfer pathways of ${ }^{14} \mathrm{C}$ in rice paddy fields. The soil samples were collected throughout Japan and taken to our laboratory where they were air dried and sieved $(<2 \mathrm{~mm})$. These sieved soils were mixed with a $\left[1,2-{ }^{14} \mathrm{C}\right]$ sodium acetate solution at the ratio of soil : solution $=0.5 \mathrm{~g}: 5 \mathrm{ml}$, and the flooded soil samples were incubated at $25^{\circ} \mathrm{C}$ for 7 days [2]. During the incubation period, the ${ }^{14} \mathrm{C}$ atoms of the sodium acetate were partitioned into solid, liquid, and gas phases. Each partitioning ratio is shown in Fig. 26.1. Approximately $63 \%$ of the total ${ }^{14} \mathrm{C}$ on average was released into the air as gaseous compounds. Partitioning ratios into solid and liquid phases were $34 \%$ and $3 \%$, respectively. These results suggest that gasification is an important pathway in the environmental transfer of ${ }^{14} \mathrm{C}$ in Japanese rice paddy fields.

When ${ }^{14} \mathrm{C}$ is released into the air, ${ }^{14} \mathrm{C}$-bearing gases must pass through the soil solution. Because soil solution $\mathrm{pH}$ affects chemical reactions such as hydrolysis and degassing of $\mathrm{CO}_{2}$, chemical forms of ${ }^{14} \mathrm{C}$-bearing gases may change in the soil solution. We, therefore, investigated relationships between $\mathrm{pH}$ and partitioning ratios of ${ }^{14} \mathrm{C}$ into the liquid phase at day 7 of incubation (Fig. 26.2). The partitioning ratio increased with increasing in $\mathrm{pH}$, and a significant correlation $(r=0.7)$ was found. These data fit well with the solubility curve of total carbonic acid in water, which refers to the sum of dissolved carbon dioxide and the carbonic acid. This observation suggested that the dominant chemical species of ${ }^{14} \mathrm{C}$ in gas forms was carbon dioxide. To confirm the effect of $\mathrm{pH}$ on the partitioning of ${ }^{14} \mathrm{C}$ into the liquid phase, a soil sample was suspended in MES [2-( $N$-morpholino)ethanesulfonic acid] buffers with the initial $\mathrm{pH}$ value adjusted to 5.5, 6.5, and 7.5 (Fig. 26.3). A control 
Fig. 26.1 Box plots for each partitioning ratio of ${ }^{14} \mathrm{C}$ into solid, liquid, and gas phases

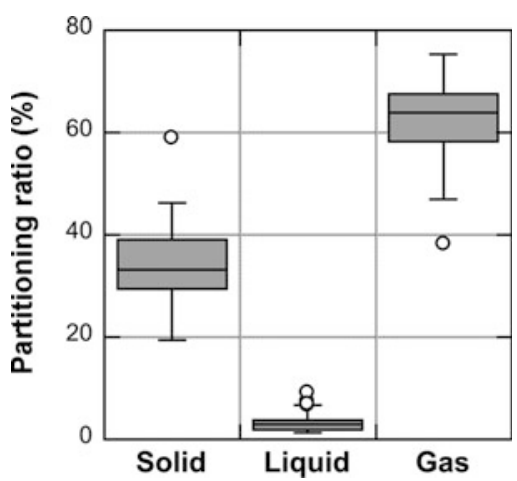

sample was prepared consisting of the soil and deionized water ( $\mathrm{pH}$ unadjusted). The partitioning ratio also increased with increasing $\mathrm{pH}$, suggesting that the partitioning ratio of ${ }^{14} \mathrm{C}$ into the liquid phase depended on the $\mathrm{pH}$ of the soil solution.

Soil-soil solution distribution coefficient $\left(K_{\mathrm{d}}\right)$ is a commonly used parameter to evaluate behaviors of radionuclides in the environment. In our study, the $K_{\mathrm{d}}$ values were calculated from activities of the ${ }^{14} \mathrm{C}$ in the solid and liquid phases at the end of incubation, and the obtained $K_{\mathrm{d}}$ value was $139 \pm 77 \mathrm{ml} \mathrm{g}^{-1}$ on average. Negatively charged anions generally have low $K_{\mathrm{d}}$ values because of simple electrostatic interaction. Our value, however, was higher than expected from the chemical form of ${ }^{14} \mathrm{CH}_{3}{ }^{14} \mathrm{COO}^{-}$. For example, Kaneko et al. [1] obtained the $K_{\mathrm{d}}$ value of $9.5 \mathrm{ml} \mathrm{g}^{-1}$ for the sorption test of acetic acid using cement materials. The reason for our high $K_{\mathrm{d}}$ value is explained next.

\subsection{Involvement of Microorganisms in the ${ }^{14} \mathrm{C}$ Behavior}

Many microorganisms inhabit rice paddy fields, and they are responsible for nutrient cycling. We studied the involvement of microorganisms in environmental transfer of ${ }^{14} \mathrm{C}$. Microorganisms in batch cultures were treated with autoclaving $\left(121{ }^{\circ} \mathrm{C}, 15 \mathrm{~min}\right)$, mixing with glutaraldehyde [final concentration of $2.5 \%$ ( $\mathrm{vol} / \mathrm{vol})]$, and mixing with cycloheximide (final concentration, $250 \mu \mathrm{g} \mathrm{ml}^{-1}$ ). Autoclaving and expose to glutaraldehyde inactivate bacteria and fungi, but exposure to cycloheximide only inhibits fungi. The partitioning ratios of ${ }^{14} \mathrm{C}$ into solid, liquid, and gas phases for each treatment sample are listed in Table 26.1. When microorganisms were treated by autoclaving and exposing to glutaraldehyde, almost all the ${ }^{14} \mathrm{C}$ added remained in the liquid phase; that is, negligible transformation of ${ }^{14} \mathrm{C}$ occurred. On the other hand, the ${ }^{14} \mathrm{C}$ atoms in the control and the cycloheximide-treated sample were partitioned into solid, liquid, and gas phases at certain ratios, and these ratios were similar between the control and the cycloheximide samples. We confirmed fungi made no contribution to partitioning of ${ }^{14} \mathrm{C}$ 
Fig. 26.2 Relationships between $\mathrm{pH}$ and partitioning ratios of ${ }^{14} \mathrm{C}$ into the liquid phase (scatter plots). Solid line shows the solubility curve of total carbonic acid in water

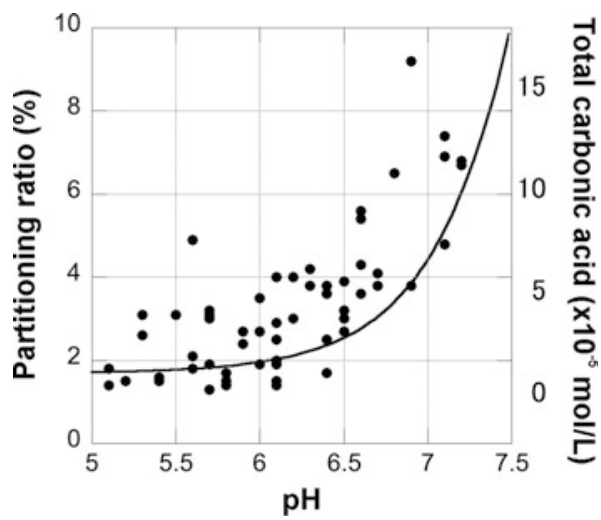

Fig. 26.3 Effect of $\mathrm{pH}$ on the partitioning of ${ }^{14} \mathrm{C}$ into the liquid phase

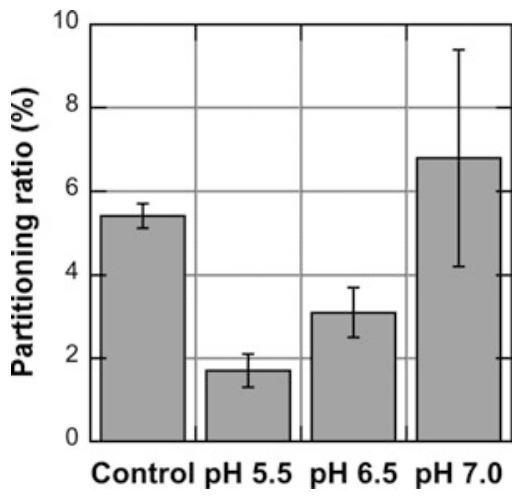

based on these results. We concluded that environmental transfer of ${ }^{14} \mathrm{C}$ in rice paddy fields was driven by bacteria, not by fungi.

To confirm incorporation of ${ }^{14} \mathrm{C}$ into bacteria cells, bacteria that were isolated from a flooding water of a paddy soil sample were cultivated on agar plates containing $\left[1,2-{ }^{14} \mathrm{C}\right]$ sodium acetate [3]. After cultivation, bacterial colonies were formed, and their autoradiography images showed that all colonies had the ability to take up ${ }^{14} \mathrm{C}$ (Fig. 26.4). In our experimental procedure, bacterial cells were consequently partitioned into the solid phase, and thus the solid phase contains the ${ }^{14} \mathrm{C}$ incorporated by bacteria, which could be one of the reasons for the relatively high $K_{\mathrm{d}}$ values.

\subsection{Transfer of ${ }^{14} \mathrm{C}$ from Soil to Rice Plants}

Soil-to-rice plant transfer factors (TFs) of ${ }^{14} \mathrm{C}$, which was defined as ${ }^{14} \mathrm{C}$ concentration in rice grains $(\mathrm{Bq} / \mathrm{kg}$-dry) divided by that in soil $(\mathrm{Bq} / \mathrm{kg}$-dry), were determined by laboratory and field experiments. In the laboratory experiment using a 
Table 26.1 The partitioning ratios of ${ }^{14} \mathrm{C}$ into solid, liquid, and gas phases for each treatment.

\begin{tabular}{|c|c|c|c|}
\hline \multirow[b]{2}{*}{ Treatment } & \multicolumn{3}{|c|}{ Partitioning ratio (\%) } \\
\hline & Solid phase & Liquid phase & Gas phase \\
\hline Control & 27.9 & 4.5 & 67.5 \\
\hline Autoclaving & 0 & 98.0 & 2.0 \\
\hline Glutaraldehyde exposure & 0 & 96.8 & 3.2 \\
\hline Cycloheximide exposure & 29.3 & 4.8 & 65.9 \\
\hline
\end{tabular}
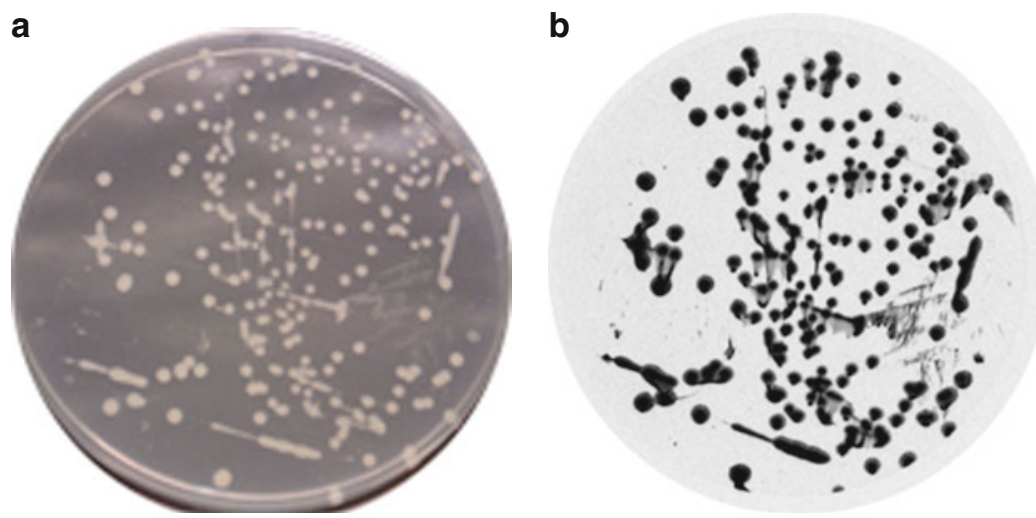

Fig. 26.4 Colonies of bacteria (a) and their autoradiography image (b). Heterotrophic bacteria have the ability to uptake ${ }^{14} \mathrm{C}$ from an agar medium

growth chamber, we grew rice plants with addition of $\left[1,2-{ }^{14} \mathrm{C}\right]$ sodium acetate. This ${ }^{14} \mathrm{C}$ compound was supplied once to rice plants in the flooding water just before blooming, and TF of $6.8 \pm 2.4$ on average was obtained. In these tracer experiments, rice plants were also cultivated without $\left[1,2-{ }^{14} \mathrm{C}\right]$ sodium acetate as negative controls in the same growth chamber as the ${ }^{14} \mathrm{C}$-treated rice. Interestingly ${ }^{14} \mathrm{C}$ was detected even from the rice grains of negative control samples. These results suggested that the ${ }^{14} \mathrm{C}$-bearing gas, which was released from bacterial cells in rice paddy soils, was fixed by the rice plants in the negative controls through photosynthesis.

We also examined the possibility of root uptake of ${ }^{14} \mathrm{C}$ by stable isotope techniques under field conditions [4]. If plant carbon originates from the atmospheric $\mathrm{CO}_{2}$, the $\delta^{13} \mathrm{C}$ values in crops can be calculated using the $\delta^{13} \mathrm{C}$ value, $-8 \%$ in air [5], and the ${ }^{13} \mathrm{C}$ fractionation ratio in photosynthesis by rice plants of -18 to $-20 \%$ [ 6,7$]$. The calculated $\delta^{13} \mathrm{C}$ values in our study ranged from $-28 \%$ to $-26 \%$, and the results implied that no soil carbon contribution occurred for white rice; however, by setting some conditions, for example, ${ }^{13} \mathrm{C}$ fractionation ratio of $19 \%$, we obtained the average TF value of $0.11 \pm 0.04$ for white rice. To compare these $\mathrm{TF}$ values obtained in laboratory and field experiments, it is necessary to pay attention to the difference between $\left[1,2-{ }^{14} \mathrm{C}\right]$ sodium acetate and the actual organic compounds present in the natural soil. 


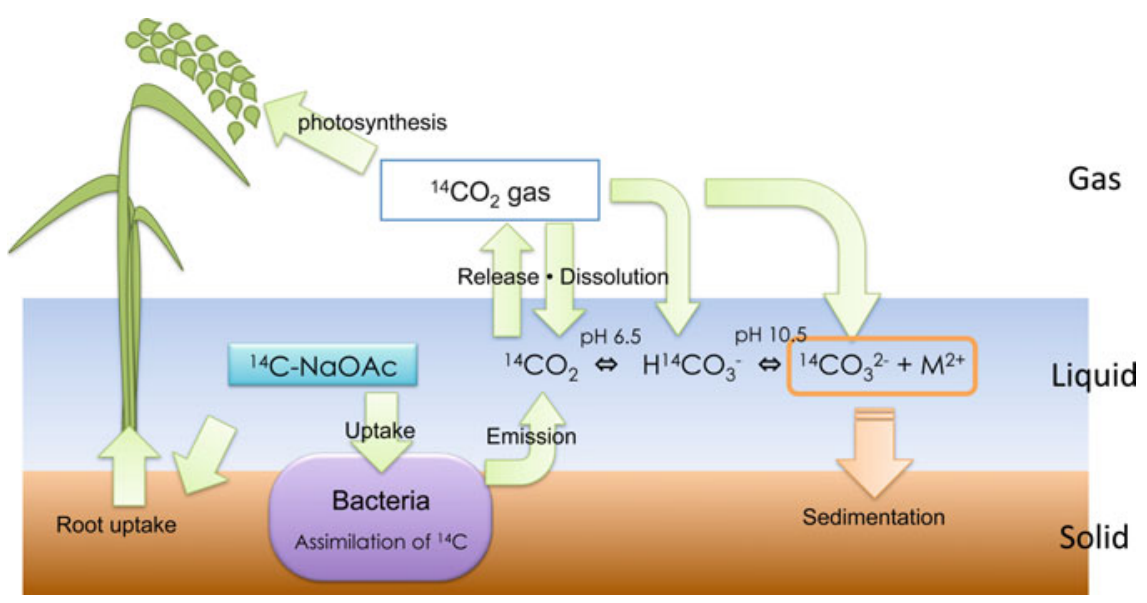

Fig. 26.5 A conceptual diagram for the behavior of ${ }^{14} \mathrm{C}$ in rice paddy fields

\subsection{Behavior of ${ }^{14} \mathrm{C}$ in Rice Paddy Fields}

From the aforementioned results, the behavior of ${ }^{14} \mathrm{C}$ in rice paddy fields could be considered as follows (a conceptual diagram appears in Fig. 26.5). When irrigation water is contaminated by ${ }^{14} \mathrm{C}$-bearing sodium acetate, the ${ }^{14} \mathrm{C}$ compound is taken up and metabolized by indigenous bacteria. A part of the ${ }^{14} \mathrm{C}$ is assimilated by the bacterial cells, and the rest of the ${ }^{14} \mathrm{C}$ is released as gaseous compounds from the cells as a result of dissimilation. The dominant chemical species of ${ }^{14} \mathrm{C}$ in gas forms is carbon dioxide, and thus some of the released ${ }^{14} \mathrm{CO}_{2}$ is dissolved in soil solution depending on $\mathrm{pH}$. For example, when the $\mathrm{pH}$ of the soil solution is less than 6.5 , most of ${ }^{14} \mathrm{C}$ in gas forms is released into the air. The released ${ }^{14} \mathrm{CO}_{2}$ is eventually taken up by rice plants during photosynthesis. When the $\mathrm{pH}$ of the soil solution is between 6.5 and $10.5,{ }^{14} \mathrm{C}$-bearing bicarbonate ion dominates in the soil solution. In addition, once ${ }^{14} \mathrm{CO}_{2}$ has been released into the air, a part of the ${ }^{14} \mathrm{CO}_{2}$ gas may be redissolved in the soil solution again as bicarbonate ion. When the $\mathrm{pH}$ of the soil solution is greater than 10.5 , although this is not probable in paddy fields, ${ }^{14} \mathrm{C}$ bearing carbonate ion dominates in the soil solution. Carbonate ion is thermally unstable and thus precipitates as carbonate minerals such as $\mathrm{CaCO}_{3}$. In these alkaline situations, the ratio of ${ }^{14} \mathrm{C}$ in the solid phase may increase as a result of the precipitation of ${ }^{14} \mathrm{C}$. Because the root uptake of ${ }^{14} \mathrm{C}$ by rice plants is negligible, gasification of ${ }^{14} \mathrm{C}$ is an important environmental transfer pathway for the safety assessment of TRU wastes, and bacteria are responsible for driving this pathway.

Acknowledgments This work has been partially supported by the Agency for Natural Resources and Energy, the Ministry of Economy, Trade and Industry (METI), Japan.

Open Access This chapter is distributed under the terms of the Creative Commons Attribution Noncommercial License, which permits any noncommercial use, distribution, and reproduction in any medium, provided the original author(s) and source are credited. 


\section{References}

1. Kaneko S, Tanabe H, Sasoh M, Takahashi R, Shibano T, Tateyama S (2002) A study on the chemical forms and migration behavior of carbon-14 leached from the simulated hull waste in the underground condition. MRS Proc 757:621-626

2. Ishii N, Koiso H, Takeda H, Uchida S (2010) Partitioning of C-14 into solid, liquid, and gas phases in various paddy soils in Japan. J Nucl Sci Technol 47:238-243

3. Ishii N, Uchida S (2011) Bacteria contributing to behavior of radiocarbon in sodium acetate. Radiat Prot Dosimetry 146:151-154

4. Tagami K, Uchida S (2010) Estimation of carbon-14 transfer from agricultural soils to crops using stable carbon isotope ratios. Waste Manag Symp Proc 36(10346):1-6

5. Ciais P, Tans P, Trolier M, White J, Francey R (1995) A large northern hemisphere terrestrial $\mathrm{CO}_{2}$ sink indicated by the ${ }^{13} \mathrm{C} /{ }^{12} \mathrm{C}$ ratio of atmospheric $\mathrm{CO}_{2}$. Science 269:1098-1102

6. O’Leary M (1981) Carbon isotope fractionation in plants. Phytochemistry 20:553-567

7. Lloyd J, Farquhar GD (1994) ${ }^{13} \mathrm{C}$ discrimination during $\mathrm{CO}_{2}$ assimilation by the terrestrial biosphere. Oecologia (Berl) 99:201-215 